ISSN 1392-3196 / e-ISSN 2335-8947

Zemdirbyste-Agriculture, vol. 105, No. 4 (2018), p. 363-368

DOI 10.13080/z-a.2018.105.046

\title{
Detection of Lettuce mosaic virus infection in South Marmara Region of Turkey and coat protein gene characterization
}

\author{
Ali KARANFIL ${ }^{1}$, Bayram CEVIK², Savas KORKMAZ \\ ${ }^{1}$ Canakkale Onsekiz Mart University \\ 17020 Canakkale, Turkey \\ E-mail: skorkmaz@comu.edu.tr \\ ${ }^{2}$ Süleyman Demirel University \\ 32260 Isparta, Turkey
}

\begin{abstract}
Lettuce mosaic virus (LMV) is considered as the most destructive virus disease of lettuce. The presence of LMV was detected and LMV isolates were comprehensively characterized at molecular level in different parts of the world. While LMV infection was reported several times in different regions of Turkey, molecular characterization of LMV isolates lagged behind in Turkey compared to other regions of the world. For this purpose, surveys were carried out in Canakkale, Balikesir and Bursa provinces, and their districts which constitute South Marmara Region of Turkey in 2013-2015 lettuce cultivation seasons. A total of 307 samples were collected from lettuce plants showing symptoms of viral infection similar to LMV. The collected samples were tested with double antibody sandwich enzyme-linked immunosorbent assay (DAS-ELISA) to determine the presence of LMV. As a result of the tests, 35 of the 307 samples were infected with LMV. Out of 35 infected samples, 15 were selected considering the provinces and their districts where they were collected for further characterization. The coat protein (CP) genes of selected isolates were amplified with reverse transcription-polymerase chain reaction (RT-PCR) to determine the sequence variation in the CP gene of Turkish isolates. RT-PCR amplified CP genes of LMV isolates were cloned and sequenced. Similarity rates and phylogenetic relationships of South Marmara Region LMV isolates with each other and world LMV isolates obtained from GenBank databases were determined.

The results showed that, identity rates of South Marmara Region LMV isolates were $96-100 \%$ and $89-99 \%$ at nucleotide level, and $97-100 \%$ and $93-100 \%$ at amino acid level among each other and with world isolates, respectively. In addition, phylogenetic analyses revealed that South Marmara Region LMV isolates were in the LMV-RoW (Rest of the World) group.
\end{abstract}

Key words: cloning, identity, phylogenetic, sequence.

\section{Introduction}

Lettuce has a large number of virus diseases causing economic losses. The most important disease is Lettuce mosaic virus (LMV) belonging to Potyvirus genus in Potyviridae family, which occurs worldwide. LMV has filamentous particles of $750 \mathrm{~nm}$ in length and $13 \mathrm{~nm}$ in diameter. It consists of a single-stranded positive sense ribonucleic acid (RNA) (+sSRNA) containing 10,080 nucleotides. The agent is transmitted with seeds and aphids in a non-persistent manner (Dinant, Lot, 1992; Moreno, Fereres, 2012). Mosaic symptoms in the leaves are generally described as the first symptom in LMV infections. Infected plants remain obviously smaller than healthy ones and if the plants are infected in the early stages, it can cause up to $50 \%$ losses (Šutić et al., 1999).

Until now, different studies have reported that LMV is present almost everywhere in Turkey. However, most of these studies were limited to detection of the virus by serological and biological methods. Only in some studies, the presence of the agent was attempted to detect by molecular methods (Erkan et al., 2013; Sertkaya, 2015). The molecular properties of LMV isolates have not been identified until now in Turkey. However, in most other countries where the presence of LMV has been reported the genetic diversity of LMV was determined at different levels (Dinant, Lot, 1992; Krause-Sakate et al., 2002; Lim et al., 2014).

As a result of molecular characterization of LMV isolates in the world, they were divided into three groups: 1) LMV-Yar (Yemen), 2) LMV-Greek (Greece) and 3) LMV-RoW (Rest of the World) (Krause-Sakate et al., 2002; German-Retana et al., 2008). Moreover, the presence of a different group of isolates not associated

Please use the following format when citing the article:

Karanfil A., Cevik B., Korkmaz S. 2018. Detection of Lettuce mosaic virus infection in South Marmara Region of Turkey and coat protein gene characterization. Zemdirbyste-Agriculture, 105 (4): 363-368. DOI 10.13080/z-a.2018.105.046 
with these three groups has been identified in recent years, and this new group was called as LMV-Cr (Catharanthus roseus) (Svanella-Dumas et al., 2014).

This study was initiated for detection of LMV, determination of its distribution in the region and the first molecular characterization of LMV in Turkey. First, Canakkale, Bursa and Balikesir provinces and their districts constituting South Marmara Region were surveyed for LMV. Then, the presence of LMV infection in lettuce samples was determined by ELISA and RTPCR. Finally, the CP genes of some LMV isolates were cloned and sequenced for molecular characterization and genetic diversity analysis. Thus, the most comprehensive research on LMV to date has been conducted in Turkey and reported in this study.

\section{Materials and methods}

Virus isolates. Field surveys were carried out in the provinces and districts of South Marmara Region (SMR) in 2013-2015 lettuce cultivation seasons. Samples were taken from plants showing typical Lettuce mosaic virus (LMV) infection symptoms and plants that appeared different from others in the field, and brought to the laboratory in the cold chain. The collected samples were first tested for the presence of LMV by the double antibody sandwich enzyme-linked immunosorbent assay (DAS-ELISA) previously reported by Clark and Adams (1977) using commercially available kit (Bioreba, Switzerland) according to the manufacturer's recommendations. Finally, test was evaluated by reader ELISA (Awareness Technology Inc., USA) measurement at $405 \mathrm{~nm}$ wavelength and samples with the optical density at $405 \mathrm{~nm}\left(\mathrm{OD}_{405}\right)$ value twice or greater than the $\mathrm{OD}_{405}$ value of the negative control were considered to be infected with LMV.

Cloning. As a result of DAS-ELISA tests, total ribonucleic acid (RNA) isolation was performed from all samples infected with LMV using the mini kit RNeasy (Qiagen, Germany), the simple direct tube (SDT) (Suehiro et al., 2005) and the CTAB (cetyl trimethylammonium bromide) methods ( $\mathrm{Li}$ et al., 2008) to determine the most appropriate RNA isolation method. The complete coat protein (CP) gene of LMV was amplified by reverse transcription-polymerase chain reaction (RT-PCR), using primer pairs SK11 LMV F (GTAGACACGAAGCTTGATGCA) and SK12 LMV R (GTGCAACCCTCTCACGCCTAA) and twostep kit RT-PCR (TaKaRa, Japan). The amplified CP gene of $15 \mathrm{LMV}$ isolates selected with consideration of the provinces and their districts from which they were obtained was cloned in accordance with the manufacturer's recommendation with kit pGEM®-T Easy Vector System II (Promega, USA). The cloned CP genes of LMV isolates were sequenced bi-directionally by automatic deoxyribonucleic acid (DNA) sequencing device using universal primers M13F and M13R (Refgen Biotechnology, Turkey). Sequences of the complete CP gene of SMR LMV isolates were deposited into the GenBank databases (Table 1).

Table 1. Properties of Lettuce mosaic virus isolates from South Marmara Region, Turkey used in this study

\begin{tabular}{|c|c|c|c|c|c|}
\hline GenBank accession No. & Isolate & Symptom $^{1}$ & Location & Year & Group $^{2}$ \\
\hline KX378988 & BLK 75 & mild chlorosis & Balıkesir & 2014 & LMV-RoW \\
\hline KX378990 & BLK 95 & dwarfing & Balıkesir & 2014 & LMV-RoW \\
\hline KX378991 & BLK 107 & dwarfing & Balıkesir & 2014 & LMV-RoW \\
\hline KX378995 & BLK 367 & mosaic & Balıkesir & 2014 & LMV-RoW \\
\hline KX378996 & BLK 383 & mosaic & Balıkesir & 2014 & LMV-RoW \\
\hline KX378997 & BLK 385 & mosaic & Balıkesir & 2015 & LMV-RoW \\
\hline KX378993 & BRS 190 & mild mosaic & Bursa & 2014 & LMV-RoW \\
\hline KX378968 & CNK 5 & severe mosaic & Canakkale & 2015 & LMV-RoW \\
\hline KX378970 & CNK 15 & necrotic spot & Canakkale & 2015 & LMV-RoW \\
\hline KX378974 & CNK 63 & mosaic & Canakkale & 2013 & LMV-RoW \\
\hline KX378978 & CNK 242 & mosaic & Canakkale & 2015 & LMV-RoW \\
\hline KX378981 & CNK 248 & mosaic & Canakkale & 2015 & LMV-RoW \\
\hline KX378982 & CNK 249 & mosaic & Canakkale & 2015 & LMV-RoW \\
\hline KX378984 & CNK 346 & mosaic & Canakkale & 2014 & LMV-RoW \\
\hline KX378987 & CNK 382 & mosaic & Canakkale & 2013 & LMV-RoW \\
\hline
\end{tabular}

${ }^{1}$ - seen on collected plants, ${ }^{2}$ - accordingly created phylogenetic tree; LMV-RoW - lettuce mosaic virus-Rest of the World

Sequence similarity and phylogenetic analysis. Some of the LMV isolates obtained from the different regions of the world found in the GenBank were used for the determination of sequence similarity rates and phylogenetic relationships of LMV isolates in software CLC Main Workbench, version 7.7.3 (Table 2). For this purpose, the complete nucleotide (NT) and deduced amino acid (AA) of the CP gene sequences SMR and world LMV isolates were aligning with program ClustalW and the similarities at NT and AA level were determined among SMR and world LMV isolates by using their CP gene. The phylogenetic relationship of LMV isolates was determined by neighbour-joining and UPGMA (unweighted pair group method with arithmetic mean) method applying Kimura 80-parameters with 1000 bootstrap replications. Also, the similarity rates of LMV isolates were obtained as a coloured matrix in Sequence Demarcation Tool, version 1.2 (SDTv1.2) (Muhire et al., 2014).
Recombination and genetic distance analysis. Detection of possible recombinants among SMR LMV isolates were searched using recombination detection methods RDP, GENECONV, Bootscan, MaxChi, Chimaera, SiScan and 3Seq, implemented in recombination detection program $R D P 4$ version 4 (Martin et al., 2015). For the detection of possible recombinant isolates, multiple alignments of NT sequence the $\mathrm{CP}$ gene of the LMV isolates aligned by the program Clustal W in the CLC Main Workbench, version 7.7.3 were transferred to $R D P 4$ analysed for recombinations.

The genetic distances of the phylogenetic groups were calculated in intra-groups and intergroup levels. Therefore, precision of the groups formed in the phylogenetic trees was also confirmed. For this, LMV isolates were divided into four groups according to phylogenetic trees and NT sequence of the CP gene of LMV isolates were aligned by ClustalW, separately. 
Table 2. Properties of world lettuce mosaic virus isolates used in multiple sequence alignment and construction phylogenetic trees

\begin{tabular}{|c|c|c|c|c|}
\hline GenBank accession No. & Isolate & Country & Group & Reference \\
\hline KF268956 & $\mathrm{Cr}$ & France & $\mathrm{LMV}-\mathrm{Cr}$ & Svanella-Dumas et al., 2014 \\
\hline JQ794776.1 & - & India & LMV-RoW & Sharma, Jain, 2013 \\
\hline KF955619.1 & Muju & Korea & LMV-RoW & Lim et al., 2014 \\
\hline AJ278854.1 & AF199 & Brazil & LMV-RoW & Krause-Sakate et al., 2005 \\
\hline U24670 & Romaine & USA & LMV-RoW & Zerbini et al., 1995 \\
\hline Z78228.1 & Gr5 & Greece & LMV-Greek & Revers et al., 1997 a \\
\hline Z78229.1 & Gr4 & Greece & LMV-Greek & Revers et al., 1997 a \\
\hline Z78230.1 & GrB & Greece & LMV-Greek & Revers et al., 1997 a \\
\hline X97705.1 & strain E & France & LMV-RoW & Revers et al., 1997 b \\
\hline X97704.2 & strain $\mathrm{O}$ & France & LMV-RoW & Revers et al., 1997 b \\
\hline Z78227.1 & Yar & Yemen & LMV-Yar & Revers et al., 1997 a \\
\hline
\end{tabular}

$\mathrm{Cr}-\underline{\text { Catharanthus roseus }}$

The calculations were performed using these alignments with the neighbour-joining method applying Kimura 2-parameter with 1000 bootstrap replications in program $M E G A 7$ (Kumar et al., 2016).

\section{Results and discussion}

$\boldsymbol{L M V}$ infection. Within the scope of the field studies, 307 samples showing LMV or virus-like symptoms were collected from SMR. According to the DAS-ELISA test results, 35 samples were infected with LMV. Twenty-four samples from 113 samples collected in Canakkale, 10 samples from 83 samples collected in Balikesir and only one sample from 111 samples collected from Bursa were infected with LMV. The rates of LMV infections in the collected samples were 21.23, 12.04 and $0.90 \%$ for Canakkale, Balikesir and Bursa, respectively. In general, the LMV infection rate in the collected samples was $11.40 \%$. In a study conducted in the Iranian lettuce field, the LMV infection rate was $21 \%$, and in another study conducted in the Eastern Mediterranean region of Turkey, the LMV infection rate was 47.1\% (Soleimani et al., 2011; Sertkaya, 2015). The result showed that infection rate of LMV was lower in SMR compared to previous studies conducted in other region of Turkey and neighbouring countries. The different LMV infection rates obtained from these studies may be explained by variation in sampling time, culture conditions and the presence of aphid vectors that play a role in the transmission of LMV. Although all sampled plants showed virus or virus-like symptoms, the infection rate was partially low $-11.40 \%$. This may be due to the possibility of the presence of other viruses such as Mirafiori lettuce big-vein virus (MiLBVV), Tomato spotted wilt virus (TSWV) and Cucumber mosaic virus (CMV) previously reported in lettuce fields in Turkey (Sertkaya, 2015). Recent reports of some of the newly emerging virus mentioned above except LMV in the studies carried out in lettuce fields in different areas of the world also supports the idea that the infection of other virus causing problems in lettuce may also be present in samples collected in this study (Soleimani et al., 2011; Al-Saleh et al., 2014; Ochoa-Martinez et al., 2014; Ciuffo et al., 2016)

Nucleic acid isolation. The detection of molecular diversity in the CP gene of SMR LMV isolates, total RNA isolation was carried out by three different RNA isolation methods mentioned previously and RT-PCR analyses were performed. An 834 bp band corresponding to the CP gene of LMV was amplified from total RNA obtained from all tested isolation methods. However, SDT method was chosen due to the speed, easiness and simplicity as well as requirement of no specific chemical components compared to the others. Since the first report of the SDT method by Suehiro et al. (2005) different researchers efficiently used the method for total nucleic acid isolation without any problems (Damayanti, Putra, 2011; Delgado et al., 2016; Karanfil, Korkmaz, 2016). Total RNA was isolated with SDT method from all samples found positive for LMV infection in DAS-ELISA tests. Furthermore, a band of the expected size was obtained from all in RT-PCR.

Nucleic acid sequence similarity rates. The multiple sequence alignment showed that SMR LMV isolates were quite similar to each other. Sequence similarity rates among the SMR were $96-100 \%$ and $97-100 \%$ in NT and AA level, respectively. Generally, isolates inform the same region showed higher similarities (Ormaz et al., 2006). As a result of comparison with the world isolates, the CP gene of SMR LMV isolates was $89-99 \%$ and $93-100 \%$ similar at NT and AA levels, respectively. The lowest sequence similarity rate between SMR and world LMV isolates was obtained with isolate Z78227.1 (Yemen) at both NT and AA levels, the highest similarity rate was obtained between X97704 (France) and JQ794776 (India) at NT level with 99\%, and between X97704 (France), JQ794776 (India) and AJ306288 (Brazil) at AA level with $100 \%$ (Fig. 1).

Phylogenetic relationships. It was observed that the phylogenetic trees constructed by neighbourjoining and UPGMA methods of SMR and world LMV isolates have very similar topologies to each other except for some differences at NT and AA levels (Figs 2 and 3).

LMV isolates were divided into four groups in phylogenetic trees as previously reported in the literature (Krause-Sakate et al., 2002; German-Retana et al., 2008; Svanella-Dumas et al., 2014). SMR LMV isolates from Turkey were included in the RoW group. The SMR isolates were closely related to each other. Isolate Z78227.1 (Yemen) was phylogenetically the most distant isolate to SMR LMV isolates. Similar results were obtained in previous molecular characterization studies performed by different researchers. LMV isolate Z78227.1 from Yemen formed a separate group in phylogenetic trees (Revers et al., 1997 a; Lim et al., 2014). It was observed that LMV isolates constituted a large number of closely related subgroups within RoW group. SMR LMV isolates appeared to be the most different among LMV isolates forming the RoW group in the phylogenetic tree based on the NT sequences. In the phylogenetic tree constructed using AA sequences of LMV isolates used in this study, it is seen that the subgroups formed are decreasing due to the increased sequence similarity closer relationship among SMR LMV isolates. 

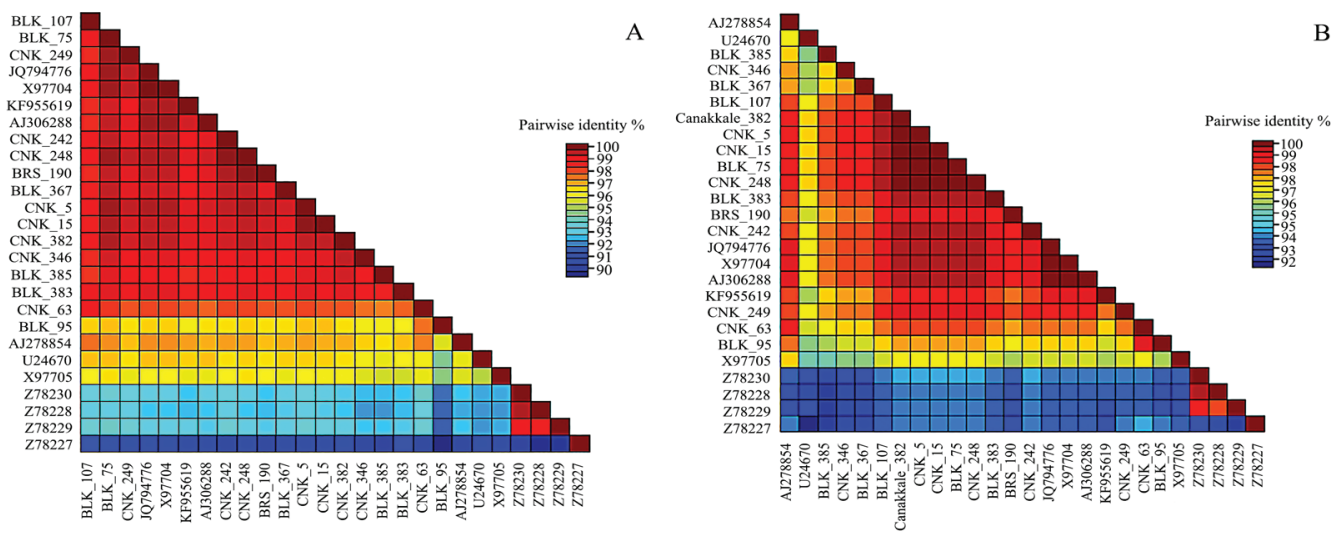

Figure 1. Coloured identity matrix showing similarities among the complete coat protein gene sequence of Lettuce mosaic virus isolates from South Marmara Region and world at (A) nucleotide (NT) and (B) amino acid (AA) levels

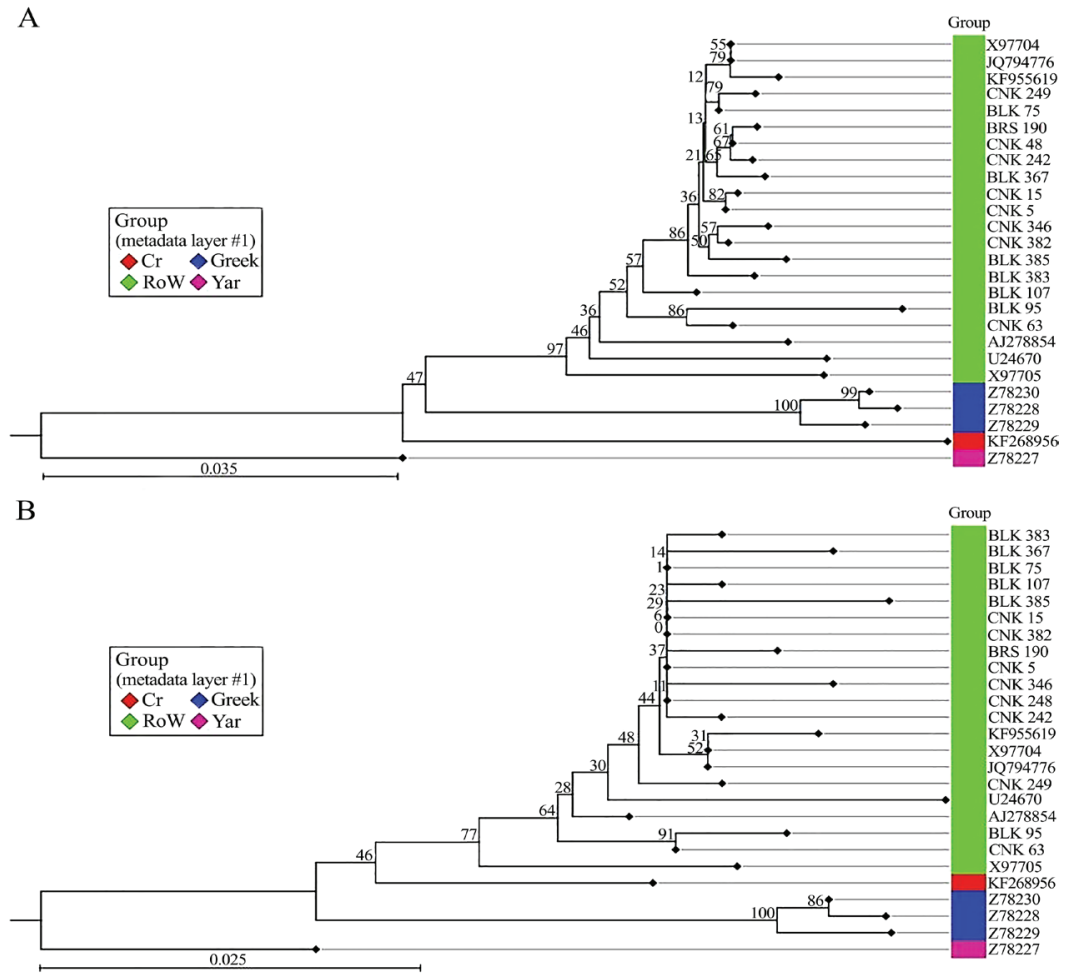

Note. Phylogenetic tree was generated by the neighbour joining method applying Kimura 80-parameters with 1000 bootstrap replications; $\mathrm{Cr}$ - Catharanthus roseus, RoW - Rest of the World, Greek - Greece, Yar - Yemen

Figure 2. Phylogenetic trees created using (A) the complete nucleotide (NT) and (B) amino acid (AA) sequences of the coat protein gene of Lettuce mosaic virus isolates from the South Marmara Region and world
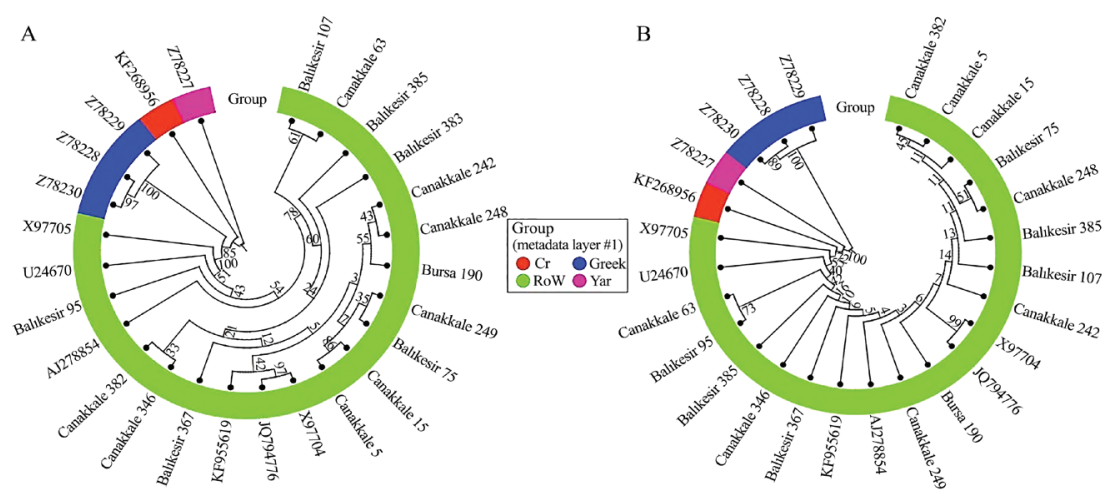

Note. Phylogenetic tree was generated by the UPGMA method applying Kimura 80-parameters with 1000 bootstrap replications; $\mathrm{Cr}$ - Catharanthus roseus, RoW - Rest of the World, Greek - Greece, Yar - Yemen.

Figure 3. Phylogenetic trees created using the complete nucleotide (NT) (A) and amino acid (AA) (B) sequences of the coat protein gene of Lettuce mosaic virus isolates from the South Marmara Region and world 
Detection of recombination and genetic distances. The existing recombination events among SMR LMV isolates were searched with program $R D P 4$ with 7 recombination detection models only one possible recombination signal was detected among the isolates by different three recombination signals. When the statistical significance of the recombination signal was considered, the one isolate (BLK 95) was possible recombinant (Table 3). However, it is necessary to obtain $P$-value less than $1.0 \times 10^{-6}$ with at least three different methods in order to consider true recombination (Ohshima et al., 2016). For this reason, complete sequences of SMR LMV isolates should be used to reach a definite decision.

According to the groups formed in phylogenetic trees, the isolates were divided into four groups and their genetic distances were calculated at intra-group and inter-group levels. The evolutionary distance coefficients within the intra-groups are considerably smaller than the intergroup values. These results support the precision of the groups in the phylogenetic trees (Zhu et al., 2016). Among the groups, the group with the highest genetic diversity was in LMV-RoW, while LMV-Greek group had the lowest genetic diversity. In the LMV-Cr and LMV-Yar groups, calculation was not done due to the presence of only one isolate in the group. Among the groups, LMV-RoW and LMV-Greek were found to be the closest to each other in terms of genetic diversity, while LMV-Cr and LMV-Yar groups were the most distant from each other (Table 4).

Table 3. The results of recombination analysis of Lettuce mosaic virus isolates from South Marmara Region by using program $R D P 4$

\begin{tabular}{cccc}
\hline Method & $\begin{array}{c}\text { Recombination } \\
\text { detected }\end{array}$ & $\begin{array}{c}\text { Average } \\
P \text {-value }\end{array}$ & $\begin{array}{c}\text { Recombinant } \\
\text { isolate }\end{array}$ \\
\hline RDP & - & - & - \\
GENECONV & - & - & - \\
BootScan & - & - & - \\
MaxChi & + & $8.809 \times 10^{-03}$ & BLK 95 \\
Chimaera & + & $1.998 \times 10^{-03}$ & BLK 95 \\
SiScan & + & $8.135 \times 10^{-03}$ & BLK 95 \\
3Seq & - & - & - \\
LARD & - & - & - \\
PhylPro & - & - & - \\
\hline
\end{tabular}

Table 4. Estimates of average evolutionary distance over sequence pairs within and between groups

\begin{tabular}{ccccc}
\hline Group & LMV-RoW & LMV-Cr & LMV-Yar & LMV-Greek \\
\hline LMV-RoW & $0.021 \pm 0.002$ & & & \\
LMV-Cr & $0.089 \pm 0.011$ & nc & nc & \\
LMV-Yar & $0.107 \pm 0.011$ & $0.125 \pm 0.013$ & $0.113 \pm 0.012$ & $0.011 \pm 0.003$ \\
LMV-Greek & $0.077 \pm 0.009$ & $0.104 \pm 0.012$ & \\
\hline
\end{tabular}

Note. The error bars represent standard deviation for evolutionary distance rates; nc - incalculable.

\section{Conclusions}

1. The presence and molecular characterization of Lettuce mosaic virus (LMV) infection have been revealed in provinces and districts of South Marmara Region (SMR) with this study and analyses revealed that SMR LMV isolates were found in the LMV-RoW (Rest of the World) group.

2. The SMR LMV isolates showed high similarities with each other.

3. There was not found recombinant LMV isolate among SMR LMV isolates; however, recombination analysis should be repeated using more gene regions or complete genomes of Turkish LMV isolates for accurate conclusion.

\section{Acknowledgements}

This study was supported by a grant (TUBITAKTOVAG 2140622) from the Scientific and Technological Research Council of Turkey.

Received 16112017 Accepted 19062018

\section{References}

1. Al-Saleh M. A., Al-Shahwan I. M., Amer M. A., Shakeel M. T., Ahmad M. H., Kamran A., Efthimiou C. E. Katis N. I. 2014. First report of Tomato spotted wilt virus in lettuce crops in Saudi Arabia. Plant Disease, 98 (11): 1591 https://doi.org/10.1094/PDIS-05-14-0444-PDN

2. Ciuffo M., Mammella M., Vallino M., Caciagli P. Turina M. 2016. Molecular identification and biological characterization of a new potyvirus in lettuce. Archives of Virology, 161 (9): 2549-2554.

https://doi.org/10.1007/s00705-016-2920-x

3. Clark M. F., Adams A. N. 1977. Characteristics of the microplate method of enzyme-linked immunosorbent assay for the detection of plant viruses. Journal of General Virology, 34 (3): 475-483.

https://doi.org/10.1099/0022-1317-34-3-475
4. Damayanti T. A., Putra L. K. 2011. First occurrence of Sugarcane streak mosaic virus infecting sugarcane in Indonesia. Journal of General Plant Pathology, 77 (1): 72-74. https://doi.org/10.1007/s10327-010-0285-7

5. Delgado H. V. E., Kaye C., Hincapie M., Boukari W. Wei C., Fernandez J. V., Mollov D., Comstock J. C., Rott P. 2016. First report of Sugarcane yellow leaf virus infecting Columbus grass (Sorghum almum) in Florida. Plant Disease, 100 (5): 1027

https://doi.org/10.1094/PDIS-10-15-1158-PDN

6. Dinant S., Lot H. 1992. Lettuce mosaic virus: a review. Plant Pathology, 41: 528-542. https://doi.org/10.1111/j.1365-3059.1992.tb02451.x

7. Erkan S., Gumus M., Paylan I. C., Duman I., Ergun M. 2013. The determination of viral agents in certain coldseason vegetables in Izmir province and its around. Ege Üniversitesi Ziraat Fakültesi Dergisi, 50 (3): 311-322 (in Turkish).

8. German-Retana S., Walter J., Gall O. L. 2008. Lettuce mosaic virus: from pathogen diversity to host interactors. Molecular Plant Pathology, 9 (2): 127-136.

https://doi.org/10.1111/j.1364-3703.2007.00451.x

9. Karanfil A., Korkmaz S. 2016. Identification and characterization of Turnip mosaic virus (TuMV) infection on canola plants (Brassica napus L.) in Canakkale province. Bitki Koruma Bülteni, 56 (2): 185-197 (in Turkish).

10. Krause-Sakate R., Le Gall O., Fakhfakh H., Peypelut M., Marrakchi M., Varveri C., Sylvie S. M. A., Lot H., Zerbini F. M., Candresse T. 2002. Molecular and biological characterization of Lettuce mosaic virus (LMV) isolates reveals a distinct and widespread type of resistancebreaking isolate: LMV-Most. Virology, 92 (5): 563-572.

11. Krause-Sakate R., Redondo E., Richard-Forget F., Jadão A. S., Houvenaghel M. C., German-Retana S., Pavan M. A., Candresse T., Zerbini F. M., Le Gall O. 2005. Molecular mapping of the viral determinants of systemic wilting induced by a Lettuce mosaic virus (LMV) isolate in some lettuce cultivars. Virus Research, 109 (2): 175-180. https://doi.org/10.1016/j.virusres.2004.12.001

12. Kumar S., Stecher G., Tamura K. 2016. MEGA7: molecular evolutionary genetics analysis version 7.0 for bigger datasets. Molecular Biology and Evolution, 33 (7): 1870-1874. https://doi.org/10.1093/molbev/msw054 
13. Li R., Mock R., Huang Q., Abad J., Hartung J., Kinard G. 2008. A reliable and inexpensive method of nucleic acid extraction for the PCR-based detection of diverse plan pathogens. Journal of Virological Methods, 154 (1-2): 48-55. https://doi.org/10.1016/j.jviromet.2008.09.008

14. Lim S., Zhao F., Yoo R. H., Igori D., Lee S. H., Lim H. S., Moon J. S. 2014. Characteristics of a Lettuce mosaic virus isolate infecting lettuce in Korea. Plant Pathology Journal, 30 (2): 183-187. https://doi.org/10.5423/PPJ.NT.12.2013.0120

15. Martin D. P., Murrell B., Golden M., Khoosal A., Muhire B. 2015. RDP4: detection and analysis of recombination patterns in virus genomes. Virus Evolution, 1 (1): vev003.

16. Moreno A., Fereres A. 2012. Virus diseases in lettuce in the Mediterranean basin. Loebenstein G., Lecoq H. (eds). Advances in virus research. Elsevier, p. 247-288

17. Muhire B. M., Varsani A., Martin D. P. 2014. SDT: a virus classification tool based on pairwise sequence alignment and identity calculation. PlosOne, 9 (9): 0108277. https://doi.org/10.1371/journal.pone.0108277

18. Ochoa-Martínez D. L., Alfonsina-Hernández J., SánchezEscudero J., Rodríguez-Martínez D., Vera-Graziano J. 2014. First report of Lettuce big-vein associated virus (varicosavirus) infecting lettuce in Mexico. Plant Disease, 98 (4): 573. https://doi.org/10.1094/PDIS-07-13-0761-PDN

19. Ohshima K., Nomiyama R., Mitoma S., Honda Y. Yasaka R., Tomimura K. 2016. Evolutionary rates and genetic diversities of mixed potyviruses in narcissus. Infection, Genetics and Evolution, 45: 213-223. https://doi.org/10.1016/j.meegid.2016.08.036

20. Ormaz B., Winter S., Koohi-Habibi M., Mosahebi G. Izadpanah K. 2006. Comparison of biological and molecular characterization of Iranian Lettuce mosaic virus isolates. Communications in Agricultural and Applied Biological Sciences, 71 (3): 1289-1294.

21. Revers F., Lot H., Souche S., Le Gall O., Candresse T., Dunez J. 1997 (a). Biological and molecular variability of Lettuce mosaic virus isolates. Phytopathology, 87 (4): 397-403. https://doi.org/10.1094/PHYTO.1997.87.4.397
22. Revers F., Yang S. J., Walter J., Souche S., Lot H., Le Gall O., Candresse T., Dunez J. 1997 (b). Comparison of the complete nucleotide sequences of two isolates of Lettuce mosaic virus differing in their biological properties. Virus Research, 47 (2): 167-177. https://doi.org/10.1016/S0168-1702(96)01411-6

23. Sertkaya G. 2015. Investigation of some viruses in lettuce and spinach fields in Hatay province of Turkey. Ziraat Fakültesi Dergisi, Mustafa Kemal Üniversitesi, 20 (1): 7-12 (in Turkish).

24. Sharma P., Jain R. K. 2013. First report of Lettuce mosaic virus infecting Lactuca sativa in India. Plant Disease, 97 (6): 849. https://doi.org/10.1094/PDIS-09-12-0827-PDN

25. Soleimani P., Mosahebi G., Habibi G. M. 2011. Identification of some viruses causing mosaic on lettuce and characterization of Lettuce mosaic virus from Tehran Province in Iran. African Journal of Agricultural Research, 6 (13): 3029-3035.

26. Suehiro N., Matsuda K., Okuda S., Natsuaki T. 2005. A simplified method for obtaining plant viral RNA for RTPCR. Journal of Virological Methods, 125 (1): 67-73. https://doi.org/10.1016/j.jviromet.2005.01.002

27. Svanella-Dumas L., Verdin E., Faure C., German-Retana S., Gognalons P., Danet J. L., Marais A., Candresse T. 2014. Adaptation of Lettuce mosaic virus to Catharanthus roseus involves mutations in the central domain of the VPg. Molecular Plant-Microbe Interactions, 27 (5): 491-497. https://doi.org/10.1094/MPMI-10-13-0320-R

28. Sutić D. D., Ford R. E., Tošić M. T. 1999. Handbook of plant virus diseases. CRC Press, $584 \mathrm{p}$.

29. Zerbini F. M., Koike S. T., Gilbertson R. L. 1995. Biological and molecular characterization of Lettuce mosaic potyvirus isolates from the Salinas Valley of California. Phytopathology, 85 (7): 746-752. https://doi.org/10.1094/Phyto-85-746

30. Zhu F., Sun Y., Wang Y., Pan H., Wang F., Zhang X., Zhang Y., Liu J. 2016. Molecular characterization of the complete genome of three Basal-BR isolates of Turnip mosaic virus infecting Raphanus sativus in China. International Journal of Molecular Science, 17 (6): E888. https://doi.org/10.3390/ijms17060888

ISSN 1392-3196 / e-ISSN 2335-8947

Zemdirbyste-Agriculture, vol. 105, No. 4 (2018), p. 363-368

DOI $10.13080 /$ z-a.2018.105.046

\title{
Salotų mozaikos viruso nustatymas Turkijos Pietų Marmario regione ir jo baltyminio apvalkalo geno apibūdinimas
}

\author{
A. Karanfil ${ }^{1}$, B. Cevik ${ }^{2}$, S. Korkmaz ${ }^{1}$ \\ ${ }^{1}$ Canakkale Onsekiz Mart universitetas, Turkija \\ ${ }^{2}$ Süleyman Demirel universitetas, Turkija
}

\section{Santrauka}

Salotų mozaikos virusas (LMV) sukelia žalingiausią salotų virusinę ligą. LMV buvo nustatytas ir jo izoliatai išsamiai apibūdinti molekuliniu lygmeniu ịvairiuose pasaulio regionuose. Nors LMV infekcija keletą kartų buvo nustatyta ivvairiuose regionuose, palyginus su kitomis šalimis, Turkija atsilieka LMV izoliatų molekulinio charakterizavimo srityje. 2013-2015 m. salotu auginimo sezono metu buvo atlikti tyrimai Turkijos Canakkale, Balikesir ir Bursa provincijose bei rajonuose, kurie sudaro Pietų Marmario regioną. Iš viso buvo surinkti 307 méginiai salotų augalų, turinčiu virusinès infekcijos simptomų. Siekiant nustatyti LMV, surinkti mėginiai buvo tirti naudojant dviguba antikūnų fermentais susietą imunosorbento tyrimą (DAS-ELISA). Tyrimas parodè, kad 35 iš 307 méginių buvo užsikrètę LMV. Siekiant juos išsamiau apibūdinti, atsižvelgiant ị provincijas ir rajonus, kur jie buvo surinkti, iš 35 užsikrèstų buvo atrinkta 15 mėginių. Siekiant nustatyti Turkijoje rastų LMV izoliatų baltyminio apvalkalo geno sekos variacija, genu sekos buvo pagausintos naudojant atvirkštinès transkripcijos polimerazès grandininę reakciją, klonuotos ir sekvenuotos. Panaudojus Genų banko duomenų bazèje pateiktas LMV sekas atlikta išskirtų LMV izoliatų baltyminio apvalkalo genų identiškumo ir filogenetinè analizè.

Tyrimo rezultatai parode, kad Pietu Marmario regiono LMV izoliatu baltyminio apvalkalo geno identiškumas nukleotidų sekose buvo 96-100 ir 89-99 \%, amino rūgščių sekose - 97-100 ir 93-100 \% atitinkamai tarpusavyje ir juos lyginant su pasaulyje apibūdintais LMV izoliatais. Be to, filogenetiniai tyrimai parode, kad LMV izoliatai iš Pietų Marmario regiono priklauso LMV-RoW grupei.

Reikšminiai žodžiai: filogenetinis, klonavimas, seka, tapatumas. 